Jurnal Indonesia Sosial Teknologi: p-ISSN: 2723 - 6609

e-ISSN : 2745-5254

Vol. 2, No. 3 Maret 2021

\title{
PENGARUH STRES KERJA, BEBAN KERJA, LINGKUNGAN KERJA TERHADAP KINERJA KARYAWAN PT. JASA MARGA (PERSERO) TBK CABANG BELMERA
}

\author{
Demak Claudia Yosephine Simanjuntak, Arfi Hafiz Mudrika dan Andre \\ Syahputra Tarigan \\ Program Studi Manajemen, Universitas Prima Indonesia \\ Email: claudiayoseph8@gmail.com, mudrika531@gmail.com, \\ andretarigan997@gmail.com
}

\begin{abstract}
Employee performance can be relied on by several factors that can improve or enhance employee performance. These factors include work stress, excessive workload and a work environment that is not conducive. This study aims to analyze the effect of work stress, workload, and work environment on employee performance at PT. Jasa Marga (Persero) Tbk Belmera Branch. Data were collected from questionnaires from 50 respondents for statistical analysis. The statistical analysis used is descriptive analysis and multiple linear regression analysis. The results showed that Job Stress (X1), Workload (X2) and Work Environment (X3) had a positive and significant effect on Employee Performance (Y) at PT. Jasa Marga (Persero) Tbk, Balmera Branch, Medan, either partially or simultaneously. The findings above illustrate that the company can implement measures to prevent work stress, workload and create a work environment to achieve more optimal employee performance.
\end{abstract}

Keyword: work stress; work load; work environment; employee performance

\begin{abstract}
Abstrak
Kinerja karyawan diidentifikasi mampu dipengaruhi oleh beberapa faktor yang dapat meningkatkan atau bahkan menurunkan kinerja karyawan. Faktor-faktor tersebut diantaranya adalah stres kerja, beban kerja yang berlebih serta lingkungan kerja yang kurang kondusif. Penelitian ini bertujuan untuk menganalisis pengaruh stres kerja, beban kerja, dan lingkungan kerja terhadap kinerja karyawan di PT. Jasa Marga (Persero) Tbk Cabang Belmera. Data penelitian dikumpulkan dari hasil kuesioner kepada 50 orang responden untuk kemudian dilakukan analisis secara statistik. Analisis statistik yang digunakan adalah analisis deskriptif dan analisis regresi linier berganda. Hasil pada penelitian menunjukkan bahwa Stres Kerja (X1), Beban Kerja (X2) dan Lingkungan Kerja (X3) berpengaruh secara positif dan signifikan terhadap Kinerja Karyawan (Y) di PT. Jasa Marga (Persero) Tbk, Cabang Balmera, Medan, baik secara parsial maupun simultan. Temuan di atas menjabarkan bahwa perusahaan hendaknya dapat menerapkan upaya-upaya untuk mencegah terjadinya stres kerja, tingginya beban kerja dan menciptakan lingkungan kerja guna mencapai kinerja karyawan yang lebih optimal.
\end{abstract}


Demak Claudia Yosephine Simanjuntak, Arfi Hafiz Mudrika dan Andre Syahputra Tarigan

Kata kunci: stres kerja; beban kerja; lingkungan kerja; kinerja karyawan.

\section{Pendahuluan}

Kinerja karyawan diidentifikasi sebagai salah satu hal pokok yang cukup penting dalam upaya mencapai tujuan perusahaan (Gultom, 2014). Kinerja karyawan diidentifikasi mampu dipengaruhi oleh beberapa faktor yang dapat meningkatkan atau bahkan menurunkan kinerja karyawan. Faktor-faktor tersebut diantaranya adalah stres kerja, beban kerja yang berlebih serta lingkungan kerja yang kurang kondusif.

Stres kerja diidentifikasi sebagai kondisi psikis karyawan yang ditandai dengan respons negatif. Kondisi stres kerja pada karyawan dinilai dapat bekontribusi terhadap kinerja karyawan, termasuk penurunan produktivitas kerja. Hal ini sesuai dengan pasal 164 hingga 166 dalam Undang-Undang Nomor 36 Tahun 2009 tentang Kesehatan yang menjelaskan bahwa kondisi pekerja dengan status kesehatan yang baik dapat berkontribusi pada tercapaianya produktivitas secara optimal. Hal ini selaras dengan studi oleh (Safitri dan Gilang 2019) yang menjabarkan bahwa stres kerja berkontribusi terhadap produktivitas karyawan.

Beban kerja diidentifikasi sebagai salah satu faktor yang berkontribusi terhadap kinerja karyawan (Adityawarman et al., 2016). Beban kerja dalam Pemendagri Nomor 12 Tahun 2008 Tentang Pedoman Analisis Beban Kerja di Lingkungan Departemen Negeri dan Pemerintah Daerah didefinisikan sebagai tingginya volume bekerja dalam satuan waktu yang harus dilaksanakan oleh karyawan. Tingginya tuntutan dalam waktu kerja yang tingggi diidentifikasi berbanding lurus dengan beban kerja karyawan. Oleh karena itu diperlukan pengaturan pendistribusian volume serta waktu kerja yang sesuai, sehingga karyawan tidak memiliki beban kerja yang tinggi.

Lingkungan kerja dinilai sebagai faktor lain yang berkontribusi terhadap kinerja karyawan (Siagian dan Khair, 2018). Lingkungan kerja yang nyaman, kondusif dan suportif dinilai akan mampu menciptakan perasaan nyaman dan aman pada karyawan, sehingga karyawan mampu memiliki produktivitas dan semangat kerja yang tinggi (Subariyanti, 2017). Lingkungan kerja diklasifikasikan menjadi lingkungan fisik dan psikis, dimana kedua hal tersebut dapat mempengaruhi kinerja seseorang pada perusahaan (Hendri, 2012).

PT. Jasa Marga (Persero) Tbk merupakan salah satu jenis Badan Usaha Milik Negara (BUMN) yang didirikan di Jakarta berdasarkan akte notaris Kartini Mulyadi,SH Nomor 1 tanggal 1 Maret 1978, selanjutnya PT. Jasa Marga (Persero) Tbk mendirikan 9 Cabang di wilayah Indonesia dan beberapa Anak Perusahaan, salah satunya Cabang Belmera (Belawan, Medan - Tanjung Morawa) yang dikelompokan cabang type B, yang didirikan berdasarkan surat keputusan Direksi PT. Jasa Marga (Persero) TBK No. 093/KPTS/JM/XII/1986 tanggal 8 Desember 1986, dengan dasar penetapan operasional surat Keputusan Presiden Nomor 61 tahun 1986, yang berkedudukan di jalan Simpang Tanjung No.1A Medan.

Peneliti mengidentifikasi terjadinya penurunan kinerja karyawan yang terlihat dari tidak tercapainya target yang ditetapkan oleh perusahaan di PT. Jasa Marga 
(Persero) Tbk. Hal ini diidentifikasi dari adanya keterlambatan serta abstain (ketidakhadiran) karyawan, sehingga menyebabkan tidak tercapainya target pada PT. Jasa Marga (Persero) Tbk. Hal ini diidentifikasi berkontribusi terhadap penurunan kinerja karyawan. Hasil tersebut sesuai dengan studi pendahuluan yang menyebutkan bahwa adanya fakor-faktor yang terjadi seperti kurang baiknya hubungan kerja antar karyawan, pekerjaan yang tidak selesai tepat pada waktunya, serta lingkungan kerja yang kurang mendukung kinerja karyawan.

Berdasarkan latar belakang permasalahan yang terjadi di perusahaan, yakni kondisi ketika seluruh karyawan harus mampu memenuhi target kerja individu sehingga menyebabkan pada kondisi stres kerja dan beban kerja berlebih yang diakibatkan oleh tingginya target kerja yang dibebankan pada karyawan dan ditambah dengan adanya pengaruh dari lingkungan kerja pada posisi pekerja lapangan dan letak kantor cabang yang kurang strategis dapat mempengaruhi kinerja karyawan. Hasil dari studi tersebut penulis melakukan penelitian dengan judul "Pengaruh stres kerja, beban kerja, dan lingkungan kerja terhadap kinerja karyawan di PT. Jasa Marga (Persero) Tbk Cabang Belmera". Penelitian ini bertujuan untuk menganalisis pengaruh stres kerja, beban kerja, dan lingkungan kerja terhadap kinerja karyawan di PT. Jasa Marga (Persero) Tbk Cabang Belmera, baik pengaruh secara simultan maupun secara parsial.

\section{Metode Penelitian}

Penelitian ini merupakan penelitian dengan analisis deskriptif dan kausal dengan pendekatan kuantitatif. Variabel pada penelitian ini terdiri dari variabel bebas yaitu Stres Kerja (X1), Beban Kerja (X2), Lingkungan Kerja (X3) dan variabel terikat yaitu Kinerja Karyawan (Y).

Penelitian dilakukan di PT. Jasa Marga (Persero) Tbk, Cabang Belmera yang beralamat di JL. Alumunium Raya no.1A Medan, Sumatera Utara. Peneltiian dilakukan selama bulan Juli hingga Oktober 2020.

Populasi pada penelitian adalah 100 orang karyawan di PT. Jasa Marga (Persero) Tbk Cabang Belmera, Medan. Sampel penelitian ditentukan berdasarkan rumus slovin dengan tingkat kesalahan sebesar $10 \%$. Jumlah sampel pada penelitian ini adalah 50 orang responden.

Data pada penelitian terdiri dari data primer, yaitu kuesioner dengan skala likert dan observasi lapangan, serta data sekunder, yaitu dokumen perusahaan serta sumber lain yang relevan. Data primer dikumpulkan dari hasil kuesioner yang telah diisi oleh 50 orang responden serta hasil observasi lapangan, sedangkan data sekunder dikumpulkan dari dokumen perusahaan terkait variabel penelitian serta sumber lain seperti buku, artikel ilmiah dan penelitian sejenis sebelumnya yang relevan dengan penelitian ini.

Analisis data pada penelitian ini menggunakan analisis deskriptif serta analisis regresi linier berganda untuk menjawab hipotesis penelitian. Analisis data dilakukan dengan bantuan software IBM SPSS Statistics. 
Demak Claudia Yosephine Simanjuntak, Arfi Hafiz Mudrika dan Andre Syahputra Tarigan

\section{Hasil dan Pembahasan}

\section{Uji Validitas dan Reliabilitas}

\section{Uji Validitas}

Uji validitas merupakan pengujian statistik untuk mebgidentifikasi validitas pada setiap aitem pada kuesioner. Uji validitas dilakukan dengan membandingkan $r$ hitung dengan $r$ tabel, dimana dikatakan valid apabila $r$ hitung $>r$ tabel. Berikut merupakan hasil uji validitas penelitian:

Tabel 1 Uji Validitas

\begin{tabular}{|c|c|c|c|c|}
\hline Variabel & No & r hitung & $r$ tabel & Kesimpulan \\
\hline \multirow{9}{*}{ Stres Kerja } & 1. & 0,510 & 0,278 & Valid \\
\hline & 2. & 0,362 & 0,278 & Valid \\
\hline & 3. & 0,516 & 0,278 & Valid \\
\hline & 4. & 0,307 & 0,278 & Valid \\
\hline & 5. & 0,618 & 0,278 & Valid \\
\hline & 6. & 0,700 & 0,278 & Valid \\
\hline & 7. & 0,601 & 0,278 & Valid \\
\hline & 8. & 0,722 & 0,278 & Valid \\
\hline & 9. & 0,651 & 0,278 & Valid \\
\hline \multirow{10}{*}{ Beban Kerja } & 10. & 0,569 & 0,278 & Valid \\
\hline & 11. & 0,580 & 0,278 & Valid \\
\hline & 12. & 0,515 & 0,278 & Valid \\
\hline & 13. & 0,492 & 0,278 & Valid \\
\hline & 14. & 0,455 & 0,278 & Valid \\
\hline & 15. & 0,301 & 0,278 & Valid \\
\hline & 16. & 0,522 & 0,278 & Valid \\
\hline & 17. & 0,464 & 0,278 & Valid \\
\hline & 18. & 0,550 & 0,278 & Valid \\
\hline & 19. & 0,494 & 0,278 & Valid \\
\hline \multirow{9}{*}{$\begin{array}{l}\text { Lingku-ngan } \\
\text { Kerja }\end{array}$} & 20. & 0,340 & 0,278 & Valid \\
\hline & 21. & 0,412 & 0,278 & Valid \\
\hline & 22. & 0,687 & 0,278 & Valid \\
\hline & 23. & 0,703 & 0,278 & Valid \\
\hline & 24. & 0,696 & 0,278 & Valid \\
\hline & 25. & 0,731 & 0,278 & Valid \\
\hline & 26. & 0,566 & 0,278 & Valid \\
\hline & 27. & 0,728 & 0,278 & Valid \\
\hline & 28. & 0,723 & 0,278 & Valid \\
\hline \multirow{3}{*}{$\begin{array}{l}\text { Kinerja } \\
\text { Karyawan }\end{array}$} & 29. & 0,679 & 0,278 & Valid \\
\hline & 30. & 0,585 & 0,278 & Valid \\
\hline & 31. & 0,450 & 0,278 & Valid \\
\hline
\end{tabular}




\begin{tabular}{lllll}
\hline 32. & 0,682 & 0,278 & Valid \\
\hline 33. & 0,667 & 0,278 & Valid \\
\hline 34. & 0,618 & 0,278 & Valid \\
\hline 35. & 0,709 & 0,278 & Valid \\
\hline 36. & 0,680 & 0,278 & Valid
\end{tabular}

Sumber: Output Olahan SPSS, 2020

Berdasarkan hasil uji validitas pada tabel 1 di atas, diketahui bahwa semua aitem pada kuesioner adalah valid, sehingga layak untuk digunakan pada penelitian.

\section{Uji Reliabilitas}

Uji reliabilitas merupakan pengujian statistika untuk mengidentifikasi keandalan suatu indikator dari kuesioner. Indikator dikatakan reliabel apabila nilai Cronbach alpha $>0,60$. Berikut merupakan hasil pengujian reliabilitas pada penelitian:

Tabel 2 Uji Reliabilitas

\begin{tabular}{ccc}
\hline Variabel & $\begin{array}{c}\text { Cronbach's } \\
\text { Alpha }\end{array}$ & Kesimpulan \\
\hline Stres Kerja & 0,721 & Reliabel \\
\hline Beban Kerja & 0,653 & Reliabel \\
\hline $\begin{array}{c}\text { Lingkungan } \\
\text { Kerja }\end{array}$ & 0,801 & Reliabel \\
\hline $\begin{array}{c}\text { Kinerja } \\
\text { Karyawan }\end{array}$ & 0,784 & Reliabel \\
\hline Sumber: Output Olahan SPSS, 2020
\end{tabular}

Berdasarkan hasil uji reliabilitas pada tabel 2 di atas, diketahui bahwa semua aitem pada kuesioner adalah reliabel, sehingga layak untuk digunakan pada penelitian.

\section{Analisis Deskriptif}

\section{Karakteristik Responden}

Karakteristik responden pada penelitian ini dijabarkan secara deskriptif untuk mengidentifikasi variabel jenis kelamin dan masa kerja responden yang bekerja di PT. Jasa Marga (Persero) Tbk. Berikut merupakan karakteristik responden pada penelitian ini:

Tabel 3 Karakteristik Responden

\begin{tabular}{llll}
\hline $\begin{array}{l}\text {l} \text { Karakteristik } \\
\text { Responden }\end{array}$ & Frekuensi & Persentase \\
\hline Jenis & Laki - laki & 35 & $70 \%$ \\
\cline { 2 - 4 } Kelamin & Perempuan & 15 & $30 \%$ \\
\hline Jumlah & & $\mathbf{5 0}$ & $\mathbf{1 0 0 \%}$ \\
\hline Masa & $1-5$ tahun & 5 & $10 \%$ \\
\hline
\end{tabular}


Demak Claudia Yosephine Simanjuntak, Arfi Hafiz Mudrika dan Andre Syahputra Tarigan

\begin{tabular}{lllll}
\hline Kerja & $\begin{array}{l}6- \\
\text { tahun }\end{array}$ & 10 & 10 & $20 \%$ \\
\cline { 2 - 4 } & $\begin{array}{l}11- \\
\text { tahun }\end{array}$ & 15 & $24 \%$ \\
\cline { 2 - 4 } & $>16$ tahun & 23 & $46 \%$ \\
\hline Jumlah & & $\mathbf{5 0}$ & $\mathbf{1 0 0 \%}$
\end{tabular}

Sumber: Output Olahan SPSS, 2020

Berdasarkan tabel 3 di atas, diketahui bahwa mayoritas responden berjenis kelamin laki-laki yaitu 35 orang responden $(70 \%)$ dengan mayoritas masa kerja lebih dari 16 tahun sebanyak 23 responden $(46 \%)$.

\section{Uji Normalitas}

Uji normalitas merupakan pengujian statistik untuk mengidentifikasi distribusi normalitas data penelitian. Uji normalitas pada penelitian ini menggunakan uji Kolmogorov-Smirnov dengan hasil sebagai berikut:

Tabel 4 Uji Normalitas

\begin{tabular}{llr}
\hline \multicolumn{3}{c}{ One-Sample Kolmogorov-Smirnov Test } \\
\hline & & \multicolumn{1}{c}{$\begin{array}{c}\text { Unstandardized } \\
\text { Residual }\end{array}$} \\
\hline $\mathrm{N}$ & Mean & 50 \\
\cline { 2 - 3 } Normal Parameters $^{\text {a }}$ & Std. Deviation & .0000000 \\
\hline Most Extreme Differences & Absolute & 1.17832131 \\
\cline { 2 - 3 } & Positive & .070 \\
\cline { 2 - 3 } & Negative & .066 \\
\hline Kolmogorov-Smirnov Z & &. .070 \\
\hline Asymp. Sig. (2-tailed) & & .493 \\
\hline
\end{tabular}

a. Test distribution is Normal.

Sumber: Output Olahan SPSS, 2020

Tabel 4 menunjukkan bahwa nilai ASMP. Sig adalah sebesar 0,968 lebih besar dari 0.05, sehingga disimpulkan bahwa data telah didistribusikan secara normal.

\section{Uji Heteroskedastisitas}

Uji heteroskedastisitas digunakan untuk mengidentifikasi ketidaksamaan variansi pada penelitian. Uji heteroskedatsitis pada penelitian ini dilakukan dengan metode scatter plot seperti berikut: 
Scatterplot

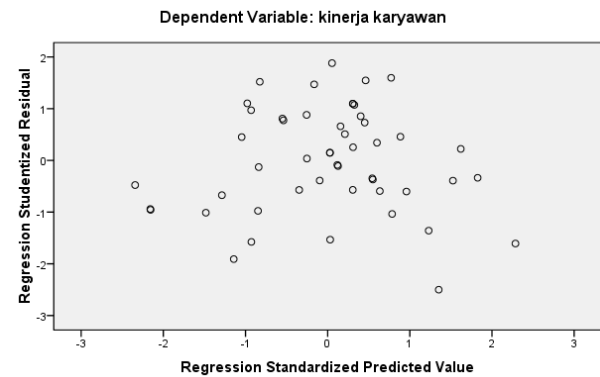

Sumber: Output Olahan SPSS, 2020

Berdasarkan gambar 2 di atas, penelitian ini dinyatakan terbebas dari heteroskedatisitas, karena titik-titik yang terdapat pada gambar tersebar secara merata. Meratanya persebaran titik tersebut mengindikasikan bahwa data penelitian telah bebas dari heteroskedatisitas.

\section{Uji Multikolinearitas}

Uji multikolinearitas pada penelitian dilakukan untuk mengidentifikasi hubungan antar variabel bebas. Uji multikolinearitas pada penelitian ini menggunakan nilai Tolearance dan nilai VIF sebagai berikut:

Tabel 5 Uji Multikolinearitas

\begin{tabular}{ccc}
\hline Variabel & \multicolumn{2}{c}{ Collinearity Statistics } \\
\cline { 2 - 3 } & Tolerance & VIF \\
\hline Stres Kerja & .389 & 2.573 \\
\hline Beban Kerja & .632 & 1.582 \\
\hline Lingkungan Kerja & .364 & 2.747 \\
\hline
\end{tabular}

Sumber: Output Olahan SPSS, 2020

Berdasarkan hasil uji multikolinearitas pada tabel 5, diketahui bahwa bahwa variabel stres kerja, beban kerja, lingkungan kerja dan kinerja karyawan telah terbebass dari multi kolinearitas dimana masing-masing nilai VIF lebih kecil dari 10.

\section{Uji Regresi Linier Berganda}

Tabel 6 Hail Uji Regresi Linier Berganda

\section{Coefficients $^{\mathrm{a}}$}

\begin{tabular}{cccccc} 
& \multicolumn{2}{c}{ Unstandardized Coefficients } & $\begin{array}{c}\text { Standardized } \\
\text { Coefficients }\end{array}$ & & \\
\cline { 2 - 3 } Model & B & Std. Error & Beta & Sig.
\end{tabular}


Demak Claudia Yosephine Simanjuntak, Arfi Hafiz Mudrika dan Andre Syahputra Tarigan

\begin{tabular}{lrrrrr}
\hline (Constant) & -6.483 & 2.498 & & -2.596 & .013 \\
\hline Stres Kerja & .306 & .082 & .313 & 3.714 & .001 \\
\hline Beban Kerja & .296 & .074 & .263 & 3.980 & .000 \\
\hline $\begin{array}{l}\text { Lingkungan } \\
\text { Kerja }\end{array}$ & .425 & .077 & .482 & 5.539 & .000 \\
\hline
\end{tabular}

a. Dependent Variable: kinerja karyawan

Sumber: Output Olahan SPSS, 2020

Berdasarkan pada tabel 6 maka dapat disusun model penelitian ini adalah sebagai berikut: $\mathrm{Y}=-6.483+0,306 \mathrm{X} 1+0,296 \mathrm{X} 2+0,425 \mathrm{X} 3$

1. Konstanta bernilai artinya ketika stres kerja, beban kerja, dan lingkungan kerja tidak bernilai nol, maka nilai dari kinerja karyawan adalah sebesar -6.483.

2. Variabel stres kerja: nilai koefisien regresi sebesar 0,306 bermakna bahwa terdapat hubungan positif antara stres kerja dengan kinerja karyawan.

3. Variabel beban kerja: nilai koefisien regresi sebesar 0,296 bermakna bahwa terdapat hubungan positif antara beban kerja dengan kinerja karyawan.

4. Variabel lingkungan kerja: nilai koefisien regresi sebesar 0,425 bermakna bahwa terdapat hubungan positif antara lingkungan kerja dengan kinerja karyawan.

\section{Uji Hipotesis}

Uji t

Uji t pada penelitian digunakan untuk mengidentifikasi pengaruh masing-masing variabel bebas terhadap variabel terikat, secara parsial. Penelitian menggunakan signifikansi $5 \%(0,05)$ dengan degree of freedom sebesar 46, sehingga nilai t tabel adalah 2,012. Uji t dinyatakan signifikan apabila $\mathrm{t}$ hitung $>\mathrm{t}$ tabel $(2,012)$. Berikut merupakan hasil pengujian hipotesis menggunakan uji t:

Tabel 7 Hasil Uji t

\begin{tabular}{|c|c|c|c|c|c|}
\hline \multirow[t]{2}{*}{ Model } & \multicolumn{3}{|r|}{$\begin{array}{c}\text { Standardiz } \\
\text { ed } \\
\text { Coefficien } \\
\text { ts }\end{array}$} & \multirow[t]{2}{*}{$\mathrm{t}$} & \multirow[t]{2}{*}{ Sig. } \\
\hline & B & Std. Error & Beta & & \\
\hline (Constant) & -6.483 & 2.498 & & -2.596 & .013 \\
\hline Stres kerja & .306 & .082 & .313 & 3.714 & .001 \\
\hline Beban kerja & .296 & .074 & .263 & 3.980 & .000 \\
\hline Lingkungan kerja & .425 & .077 & .482 & 5.539 & .000 \\
\hline
\end{tabular}

Dependent Variable: kinerja karyawan

Sumber: Output Olahan SPSS, 2020

Berdasarkan tabel 7 di atas, diketahui bahwa: 
1. Variabel stres kerja diidentifikasi memiliki nilai $t_{\text {hitung }}$ sebesar 3,714 lebih besar daripada nilai $\mathrm{t}_{\text {tabel }}$ 2,012, dengan tingkat signifikansi, $001<0,05$. Hasil penelitian menunjukkan bahwa $\mathrm{H}_{1}$ diterima dan $\mathrm{H}_{0}$ ditolak. Hal ini menunjukkan bahwa stres kerja secara parsial berpengaruh positif dan signifikan terhadap kinerja karyawan pada PT. Jasa Marga (Persero) TBK, Cabang Belmera Medan. Hasil penelitian ini sesuai dengan penelitian (Nur 2013) yang menjelaskan bahwa stress kerja dapat berpengaruh secara signifikan terhadap kinerja karyawan dengan hasil variabel stres kerja berpengaruh positif signifikan secara simultan dan parsial terhadap kinerja karyawan di Universitas Khairun Ternate. Stres kerja pada karyawan dapat diminimalisasi dengan cara memberikan fasilitas relaksasi dan hiburan pada karyawan, seperti adanya family gathering dan fasilitas lain yang dapat dilakukan perusahaan untuk menekan angka stres kerja pada karyawan.

2. Variabel beban kerja diidentifikasi memiliki nilai thitung sebesar 3,980 lebih besar daripada nilai $t_{\text {tabel }} 2,012$, dengan tingkat signifikansi $0,000<0,05$. Hasil penelitian menunjukkan bahwa $\mathrm{H}_{1}$ diterima dan $\mathrm{H}_{0}$ ditolak. Hal ini menunjukkan bahwa beban kerja secara parsial berpengaruh positif dan signifikan terhadap kinerja karyawan pada PT. Jasa Marga (Persero) TBK, Cabang Belmera, Medan. Hasil penelitian didukung oleh studi (Nabawi 2019) menjelaskan bahwa beban kerja dapat mempengaruhi kinerja karyawan di Dinas PUPR Kabupaten Aceh Tamiang, baik secara parsial maupun simultan. Minimalisasi beban kerja dapat dilakukan dengan cara penyesuaian kompetensi karyawan dengan penempatan posisi yang di tempat kerja yang sesuai dengan latar belakang. Hal ini dinilai dapat mengurangi terjadinya peningkatan beban kerja, sebab karyawan dapat melakukan pekerjaan dengan optimal sesuai latar belakang pendidikan serta pengalaman.

3. Variabel lingkungan kerja diidentifikasi memiliki nilai $t_{\text {hitung }}$ sebesar 5,539 lebih besar daripada nilai $t_{\text {tabel }} 2,012$, dengan tingkat signifikansi $0,000<0,05$. Hasil penelitian menunjukkan bahwa $\mathrm{H}_{1}$ diterima dan $\mathrm{H}_{0}$ ditolak. Hal ini menunjukkan bahwa lingkungan kerja secara parsial berpengaruh positif dan signifikan terhadap kinerja karyawan pada PT. Jasa Marga (Persero) TBK, Cabang Belmera Medan. Hasil penelitian ini selaras dengan dengan studi oleh (Potu 2013) yang menyebutkan bahwa lingkungan kerja berpengaruh signifikan secara simultan dan parsial terhadap kinerja karyawan. Pengaturan lingkungan kerja yang nyaman dan pemenuhan kebutuhan fasilitas dalam bekerja diidentifikasi mampu menciptakan kondisi lingkungan kerja yang optimal untuk peningkatan produktivitas serta kinerja karyawan. Hal ini sesuai dengan studi yang menjelaskan bahwa optimalisasi kinerja karyawan dapat dilakukan melalui pengaturan tempat kerja yang layak dan sesuai, seperti pengaturan suhu, penerangan, kelembapan dan ruang gerak bebas bagi karyawan di tempat kerja. 
Demak Claudia Yosephine Simanjuntak, Arfi Hafiz Mudrika dan Andre Syahputra Tarigan

\section{Uji F}

Uji F merupakan pengujian secara statitik untuk mengidentifikasi pengaruh variabel independen terhadap variabel dependen secara simultan atau bersamaan. Berikut merupakan hasil pengujian hipotesis menggunakan uji $\mathrm{F}$ :

Tabel 8 Hasil Uji F

\begin{tabular}{lccccc}
\hline \multicolumn{7}{c}{ ANOVA $^{\mathbf{b}}$} \\
\hline & $\begin{array}{c}\text { Sum of } \\
\text { Squares }\end{array}$ & df & $\begin{array}{c}\text { Mean } \\
\text { Square }\end{array}$ & F & Sig. \\
\hline Regression & 467.586 & 3 & 155.862 & 105.384 & $.000^{\text {a }}$ \\
\hline Residual & 68.034 & 46 & 1.479 & & \\
\hline Total & 535.620 & 49 & & & \\
\hline Sumber: Output Olahan SPSS, 2020
\end{tabular}

Berdasarkan hasil yang didapat pada tabel 8 di atas, diketahui bahwa nilai signifikansi menunjukkan nilai $0,000<0,05$. Hal tersebut bermakna bahwa variabel stress kerja, beban kerja dan lingkungan kerja secara bersama-sama dapat berpengaruh secara signfiikan terhadap kinerja karyawan pada PT. Jasa Marga (Persero) TBK, Cabang Belmera Medan.

\section{Uji Koefisien Determinasi}

Uji koefisien determinasi digunakan untuk mengidentifikasi besaran nilai variabel terikat yaitu kinerja karyawan, yang dijelaskan oleh variabel bebas yaitu stres kerja, beban kerja dan lingkungan kerja. Berikut merupakan hasil uji koefisien determinasi:

\section{Tabel 9 Hasil Uji Koefisien Determinasi}

\begin{tabular}{|c|c|c|c|c|}
\hline \multicolumn{5}{|c|}{ Model Summary $^{\mathbf{b}}$} \\
\hline $\mathrm{R}$ & $\begin{array}{c}\mathrm{R} \\
\text { Square }\end{array}$ & $\begin{array}{l}\text { Adj. R } \\
\text { Square }\end{array}$ & $\begin{array}{l}\text { Std. Error } \\
\text { of the } \\
\text { Estimate }\end{array}$ & DW \\
\hline $.934^{\mathrm{a}}$ & .873 & .865 & 1.21614 & 2.248 \\
\hline
\end{tabular}

Sumber: Output Olahan SPSS, 2020

Berdasarkan data pada tabel 9, diidentifikasi bahwa nilai Adjusted $R$ Square adalah $0,865(86,5 \%)$. Hal ini bermakna bahwa variabel stres kerja $\left(\mathrm{X}_{1}\right)$, beban kerja $\left(\mathrm{X}_{2}\right)$, dan lingkungan kerja $\left(\mathrm{X}_{3}\right)$ dapat menjelaskan variabel Kinerja Karyawan $(\mathrm{Y})$ dengan nilai $86,5 \% \%$, sedangkan nilai sisanya sebesar $13,5 \%$ dijelaskan oleh variabel bebas lainnya yang tidak diteliti dalam penelitian ini. Misalnya: budaya organisasi, gaya kepemimpinan, motivasi kerja dan lainnya. 
Pengaruh Stres Kerja, Beban Kerja, Lingkungan Kerja terhadap Kinerja Karyawan PT. Jasa Marga (Persero) Tbk Cabang Belmera

\section{Kesimpulan}

Berdasarkan hasil penelitian dan pembahasan yang telah diuraikan pada bab sebelumnya, maka dapat ditarik kesimpulan sebagai berikut:

Stres kerja secara parsial berpengaruh positif dan signifikan terhadap kinerja karyawan PT. Jasa Marga (Persero) TBK, Cabang Belmera, Medan. Beban kerja secara parsial berpengaruh positif dan signifikan terhadap kinerja karyawan PT. Jasa Marga (Persero) TBK, Cabang Belmera, Medan. Lingkungan kerja secara parsial berpengaruh positif dan signifikan terhadap kinerja karyawan PT. Jasa Marga (Persero) TBK, Cabang Belmera, Medan. Dan Stres kerja, beban kerja, dan lingkungan kerja secara simultan berpengaruh positif dan signifikan terhadap terhadap kinerja karyawan PT. Jasa Marga (Persero) TBK, Cabang Belmera, Medan. 
Demak Claudia Yosephine Simanjuntak, Arfi Hafiz Mudrika dan Andre Syahputra Tarigan

\section{Bibliography}

Adityawarman, Y., Sanim, B., \& Sinaga, B. M. (2016). Pengaruh Beban Kerja terhadap Kinerja Karyawan PT. Bank Rakyat Indonesia (persero) Tbk Cabang Krekot. Jurnal Manajemen Dan Organisasi, 6(1), 34. https://doi.org/10.29244/jmo.v6i1.12182

Cahyana, I. G. S., \& Jati, I. K. (2017). Pengaruh Budaya Organisasi, Stres Kerja Dan Kepuasan Kerja Terhadap Kinerja Pegawai. E-Jurnal Akuntansi, 18(2), 13141342.

Dewi, S. K., \& Frianto, A. (2013). Pengaruh Lingkungan Kerja Terhadap Kinerja Karyawan Melalui Motivasi. Jurnal Ilmiah Manajemen, 1(4).

Erawati, I., Darwis, M., \& Nasrullah, M. (2017). Efektivitas Kinerja Pegawai pada Kantor Kecamatan Pallangga Kabupaten Gowa. Jurnal Office, 3(1), 13. https://doi.org/10.26858/jo.v3i1.3450

Evita, S. N., Muizu, W. O. Z., \& Atmojo, R. T. W. (2017). Penilaian Kinerja Karyawan Dengan Menggunakan Metode Behaviorally Anchor Rating Scale dan Management By Objectives (Sudi kasus pada PT Qwords Company International). Pekbis Jurnal, 9(1), 18-32.

Gultom, D. K. (2014). Pengaruh Budaya Organisasi Perusahaan Dan Motivasi Terhadap Kinerja Karyawan Pada Pt. Perusahaan Gas Negara (Persero) Tbk Medan. Jurnal Manajemen Dan Bisnis, 2, 176-184.

Hendri, E. (2012). Pengaruh Lingkungan Kerja Fisik Dan Non Fisik Terhadap Kepuasan Kerja Karyawan Pada PT. Asuransi Wahana Tata Cabang Palembang. Jurnal Media Wahana Ekonomika, 9(3), 1-16.

Lumban Gaol, N. T. (2016). Teori Stres: Stimulus, Respons, dan Transaksional. Buletin Psikologi, 24(1), 1. https://doi.org/10.22146/bpsi.11224

Nabawi, R. (2019). Pengaruh Lingkungan Kerja, Kepuasan Kerja dan Beban Kerja Terhadap Kinerja Pegawai. Maneggio: Jurnal Ilmiah Magister Manajemen, 2(2), 170-183. https://doi.org/10.30596/maneggio.v2i2.3667

Nasution, M. I. (2017). Pengaruh Stres Kerja, Kepuasan Kerja Dan Komitmen Organisasi Terhadap Turnover Intention Medical Representative. MIX: Jurnal Ilmiah Manajemen, 7(3), 224238. https://doi.org/10.22441/jurnal_mix

Nur, S. (2013). Konflik, Stres Kerja, dan Kepuasan Kerja Pengaruhnya Terhadap Kinerja Pegawai pada Universitas Khaitus Ternate. Jurnal EMBA: Jurnal Riset Ekonomi, Manajemen, Bisnis Dan Akuntansi, 1(3), 739-742. https://doi.org/10.1109/siu.2009.5136498 
Pengaruh Stres Kerja, Beban Kerja, Lingkungan Kerja terhadap Kinerja Karyawan PT. Jasa Marga (Persero) Tbk Cabang Belmera

Pemendagri Nomor 12 Tahun 2008 tentangPedoman Analisis Beban Kerja di Lingkungan Departemen Negeri dan Pemerintah Daerah.

Potu, A. (2013). Kepemimpinan, Motivasi, Dan Lingkungan Kerja Pengaruhnya Terhadap Kinerja Karyawan Pada Kanwil Ditjen Kekayaan Negara Suluttenggo Dan Maluku Utara Di Manado. Jurnal Riset Ekonomi, Manajemen, Bisnis Dan Akuntansi, 1(4), 1208-1218. https://doi.org/10.35794/emba.v1i4.2894

Putra, M. T. P., \& Prihatsanti, U. (2016). Hubungan Antara Beban Kerja Dengan Intensi Turnover Pada Karyawan Di Pt. "X." Empati, 5(2), 303-307.

Safitri, A. E., \& Gilang, A. (2019). Pengaruh Stres Kerja Terhadap Produktivitas Kerja Karyawan pada PT. Telkom Witel Bekasi. Jurnal Ecodemica, 3(3), 170-180. https://doi.org/10.35724/mjpa.v2i01.2454

Siagian, T. S., \& Khair, H. (2018). Pengaruh Gaya Kepemimpinan Dan Lingkungan Kerja Terhadap Kinerja Karyawan Dengan Kepuasan Kerja Sebagai Variabel Intervening. Maneggio: Jurnal Ilmiah Magister Manajemen, 1(1), 59-70. https://doi.org/10.30596/maneggio.v1i1.2241

Sitepu, A. (2013). Beban Kerja Dan Motivasi Pengaruhnya Terhadap Kinerja Karyawan Pada Pt. Bank Tabungan Negara Tbk Cabang Manado. Jurnal EMBA: Jurnal Riset Ekonomi, Manajemen, Bisnis Dan Akuntansi, 1(4), 1123-1133. https://doi.org/10.35794/emba.v1i4.2871

Sofyan, D. K. (2013). Pengaruh Lingkungan Kerja Terhadap Kinerja Kerja Pegawai BAPPEDA. Malikussaleh Industrial Engineering, 2(1), 18-23.

Subariyanti, H. (2017). Hubungan Motivasi Kerja dan Kepuasan Kerja Terhadap Kinerja Karyawan PTLR Batan. Jurnal Ecodemica, 1(2), 224-232. http://ejournal.bsi.ac.id/ejurnal/index.php/ecodemica/article/view/2102/pdf

Trang, D. S. (2013). Gaya Kepemimpinan Dan Budaya Organisasi Pengaruhnya Terhadap Kinerja Karyawan. Jurnal EMBA: Jurnal Riset Ekonomi, Manajemen, Bisnis Dan Akuntansi, 1(3), 208-216. https://doi.org/10.32832/inovator.v7i1.1462

Undang-Undang Nomor 36 Tahun 2009 Tentang Kesehatan 